were recorded. Videos were analysed by an experienced gastroenterologist blinded to the clinical data. Markers of coeliac disease such as scalloping, mosaic pattern and loss of folds were assessed. A diagnosis of coeliac disease was further supported by not only CE appearances but also combinations of HLA typing (DQ-2 or DQ-8), gluten challenge/response to a gluten free diet and in some cases repeat duodenal biopsy.

Results 91 patients, 62 female, median age 47 years, (range 18-89 years) underwent CE. Indications were: coeliac serology negative VA ( $n=31)$, MG1-2 $(n=25)$, positive coeliac serology with normal biopsy $(n=8)$, miscellaneous $(n=27) \cdot 12 / 91(13 \%)$ had features of coeliac disease on CE. In addition, there were 3 cases of Crohn's disease (table 1). In patients with coeliac antibody negative VA CE secures a diagnosis of coeliac or Crohn's in 9/31 (29\%) significantly more than in other groups $(p=0.0344)$.

Conclusion CE may have a role in the assessment of patients with coeliac antibody negative villous atrophy. Its routine use is not supported in other causes of equivocal coeliac disease.

Competing interests None.

Keywords capsule endoscopy, coeliac.

\section{PTU-043 DOES CAPSULE ENDOSCOPY HAVE A ROLE IN EQUIVOCAL COELIAC DISEASE?}

doi:10.1136/gut.2011.239301.171

K E Evans, ${ }^{*}$ R Sidhu, K Drew, M E McAlindon, D S Sanders Department of Gastroenterology, Royal Hallamshire Hospital, Sheffield, UK

Introduction Endomysial antibody (EMA) and tissue transglutaminase (tTG) antibody testing is used to investigate for coeliac disease. Demonstration of villous atrophy (VA) on small bowel biopsy in the presence of positive serology is considered the gold standard for diagnosis. Difficulty in diagnosis may arise for several reasons. A minority of patients with coeliac disease have antibody negative disease. Some patients with positive antibodies may have histological changes that fall short of VA (Marsh Grade 1 and 2 (MG1-2)). Finally, not all VA is caused by coeliac disease. The aim of this study was to assess the usefulness of capsule endoscopy (CE) in equivocal coeliac disease.

Methods Data from all patients with equivocal coeliac disease who underwent CE between 2004 and 2010 in a tertiary gastroenterology department were analysed. Group 1: antibody negative VA; group 2: MG1-2; group 3: positive coeliac serology with normal duodenal biopsy; group 4: miscellaneous including strong family history, refusal of gastroscopy, and non- gastrointestinal presentation of probable coeliac disease. Demographic data, indication for CE, serology and histology

Table 1 PTU-043

\begin{tabular}{llll}
\hline & Normal CE $(\mathbf{n})$ & $\begin{array}{l}\text { Features of } \\
\text { coeliac }\end{array}$ & $\begin{array}{l}\text { Other CE } \\
\text { diagnosis }\end{array}$ \\
\hline Antibody -ve VA $\mathrm{n}=31$ & 22 & 7 & 2 Crohn's \\
MG1-2 $\mathrm{n}=25$ & 23 & 1 & 1 Crohn's \\
+ve antibody, normal biopsy $\mathrm{n}=8$ & 7 & 1 & 0 \\
Misc $\mathrm{n}=27$ & 24 & 3 & 0 \\
\hline
\end{tabular}

